\title{
Postfoundationalism, deconstruction and the hope that motivates research in Practical Theology
}

\author{
Johann-Albrecht Meylahn ${ }^{1}$ \\ Research Associate: Department of Practical Theology \\ University of Pretoria
}

\begin{abstract}
This article is a critical dialogue between postfoundationalism and deconstruction seeking a way of doing theology, specifically Practical Theology, without universal foundations, in the context of a discussion with Wentzel van Huyssteen. Can postfoundationalism, complemented by the critical contribution of deconstruction, pave a way for doing theology that is open to the global multi-disciplinary dialogue? This would mean a way of doing theology that takes the social constructions of the local seriously, yet can move beyond the local into a global dialogue without recourse to universal foundations. In this article postfoundationalism does indeed pave a way for this global dialogue between the various local constructions while deconstruction critically guides this process so that it is not only a dialogue between the dominant constructions of the powerful, but that space is created for the marginalized voices to be heard in the global dialogue. This move beyond the confines of the local into the global multi-disciplinary dialogue is the hope that motivates research in Practical Theology that has relevance beyond its own context and discipline.
\end{abstract}

\section{INTRODUCTION}

I would like to begin this essay with a text taken from the book of the prophet Isaiah chapter 2 the verses 1-5. This is what Isaiah son of Amos saw concerning Judah and Jerusalem:

\footnotetext{
${ }^{1} \mathrm{Dr}$ J-A Meylahn is Pastor of the Evangelisch-Lutherische St Petersgemeinde Pretoria and a research assosicate of Prof Dr J C Müller, Department of Practical Theology, Faculty of Theology, University of Pretoria. The article is a reworked version of a paper presented at the University of Pretoria, $1^{\text {st }}$ of August 2005, at a Practical Theology-Seminar: In Conversation with Prof Wentzel van Huyssteen about Postfoundationalism and Practical Theology.
} 
In the last days the mountain of the Lord's temple will be established as chief among the mountains; it will be raised above the hills, and all nations will stream to it. Many peoples will come and say, "Come let us go up the mountain of the Lord, to the house of the God of Jacob. He will teach us his ways, so that we may walk in his paths." The law will go out from Zion, the word of the Lord from Jerusalem. He will judge between the nations and will settle disputes for many peoples. They will beat their swords into ploughshares and their spears into pruning hooks. Nation will not take up sword against nation, nor will they train for war anymore. Come, O house of Jacob, let us walk in the light of the Lord.

(New International Version)

These verses will accompany this essay which is about the hope that inspires research in practical theology within the context of postfoundationalism and deconstruction as I believe the image of the prophetically anticipated temple can serve as a metaphor which has the power to inspire research, to which I will return later.

In Practical Theology or for that matter any academic discipline, we are continually building temples. We are constructing realities that give meaning and purpose to our experiences. I will be using the metaphor of temple for these constructed realities that give meaning and purpose to our existence.

In research we are either in the process of protecting an already constructed temple, or in the process of building a new floor in this temple, or if one is extremely brave building a completely new temple. Within the context of these prophetic verses these temples we are busy constructing can be compared with the temple in Jerusalem. Yet the prophet Isaiah is not speaking about the temple in Jerusalem, but about a temple which is not yet constructed, a temple still to come and maybe always still to come. He actually does not say a single word about the temple in Jerusalem, but by not saying anything he says everything about the temple in Jerusalem, but he says everything by giving us the promise of the temple always still to come. I will borrow this metaphor from Isaiah, of the temple always still to come, as an eschatological temple which breaks into the present as hope and therefore motivates research.

\section{CONSTRUCTING TEMPLES IN POSTMODERNITY}

To construct a temple in postmodernity is quite a challenge, because we have to construct these temples without any plans, whereas in modernity these temples were constructed on absolute universal truths. In postmodernity these absolute plans have been taken from us. Professor Wentzel van Huyssteen 
describes postmodernism as follows: "Postmodernism is, as I see it, first of all a very pointed rejection of all forms of epistemological foundationalism, as well as of its ubiquitous, accompanying metanarratives that so readily claim to legitimize all our knowledge, judgements, decisions, and actions" (Van Huyssteen 1997:2). Postmodernism challenged the foundationalism of modernity. "Foundationalism, as is generally defined today, is the thesis that all our beliefs can be justified by appealing to some item of knowledge that is self-evident or indubitable" (Van Huyssteen 1997:2).

Today, within the postmodern paradigm, we have only relative, local cultural-linguistic truths with which to construct temporary temples. This Professor van Huyssteen calls nonfoundationalism. There is of course another possibility and that is to deny or ignore the developments in philosophy and continue constructing temples as if we do have access to absolute and universal truths which is a return to foundationalism or fundamentalism. A very dangerous situation is to either have foundational temples which refuse to communicate with other temples or non-foundational temples which are so relative to their cultural-linguistic context that there is no common basis to facilitate communication between the temples. This lack of communication in a global village where we are forced together through communication networks and an interdependent global economic system is not only dangerous, but it seems rather absurd as we are living in a global communication and information age. In such an age we cannot be dealing with local, cultural-linguistic and paradigm specific temples which are closed in on themselves because it is only within their own paradigms and culturallinguistic metaphors and conventions that they can provide meaning for their specific local context.

Into this context of local, relative, contextual and fideist temples or fundamental universal temples comes postfoundationalism that moves beyond the foundationalist temples of fundamentalism as well as the relative, contextual and local temples. Postfoundationalism creates a platform for universal communication which is so vitally important in a global village that needs to survive without war on terrorism or fundamentalist groups attacking each other in the name of universal truths. Postfoundationalism wants to make two moves:

First, it fully acknowledges contextuality, the epistemically crucial role of interpreted experience, and the way that tradition shapes the epistemic and nonepistemic values that inform our reflection about God and what some of us believe to be God's presence in this world. At the same time, however, a postfoundationalist notion of rationality in theological reflection claims to point creatively beyond 
the confines of the local community, group, or culture towards a plausible form of interdisciplinary conversation.

(Van Huyssteen 1997:4)

This is the hope that I discovered in postfoundationalism as it provides a meaningful way to construct temples that can contribute to global communication and move beyond the violence of relativity or fundamentalism.

\section{THE POSTFOUNDATIONALIST TEMPLE}

Postfoundationalism provides us with certain tools with which to construct new temples or renovate the old temples of the past. I would like to firstly discuss some of these tools that are used in the construction of this temple and then look at the temple which is created.

\subsection{Critical Realism}

I mentioned that within postmodernity there are no plans to build a temple and there are no foundations. The only tools we have to build the temple are localised, historic, cultural-linguistic truths which are only relative truths as they are a certain historically situated, socio-cultural perspective of the truth. The temples that can be constructed within postmodernity are culturallinguistic constructions relative to the historical and social context of construction. This is an impossible situation as it breaks down the basis for communication. Postfoundationalism claims that within the scientific community there was a certain development, namely "qualified scientific realism" (Van Huyssteen 1997:129). Qualified scientific realism argues that language does indeed refer to something and therefore there is a limit to the relativism. The question that needed to be asked is: to what extent does this language (scientific) refer to the reality out there (Van Huyssteen 1997:130)? The same question can be asked in the religious or theological context: To what extent does what we talk about refer to something real? Or is all language in academic research only fiction, useful fiction, but fiction all the same? These questions asked within the scientific community were transferred to the theological community by theologians like McFague, Peacocke and Soskice. This movement became known as critical realism. This is the first tool that can be used in the construction of the temple in postfoundationalism.

The texts in academic research do indeed refer to something, in other words there is a reference. This gives academic research a certain critical foundation once more. Critical realism is not the same as realism where it was 
believed that one had direct access to reality. Critical realism is very aware of the fact that there is no direct access to reality and that the texts are always metaphors of reality.

This first tool gives us the ability to start building temples with slightly firmer foundations again. But if critical realism still is metaphoric then these metaphors are dependent on the historic, socio-cultural-linguistic setting of the metaphors. In other words, the different temples still stand isolated, bound to their specific context or paradigm.

In science you have temples looking at a certain aspect of reality and in theology you have another temple looking at a totally different aspect of reality, without there being any real common denominator for communication between these temples. Within postfoundationalism as proposed by Van Huyssteen there is believed to be a certain degree of overlap between science and theology. The place where they meet is not the aspects of reality under scrutiny, but the reasoning strategies or shared rational resources (Van Huyssteen 2005) which are used in the construction of the temples. They use similar tools (reasoning strategies) to construct their temples. Science and theology have similar ways of reflecting and a similar understanding of what knowledge is, therefore they might not agree on the reference of their texts, but they certainly can make sense of each other's texts (temples) because they are constructed on similar principles of how knowledge is acquired (epistemology).

Theology deals predominantly with experience, but religious experience which points beyond the reality of experience. Science deals with "reality" but it is always a combination of discovery, exploration as well as construction and invention. "The most fundamental claim of critical realism is therefore that while all theories and models are partial and inadequate, the scientist not only discovers as well as creates, but with good reasons also believes that his or her theories actually refer" (Van Huyssteen 1997:134). This is true for all users of models of discovery, that in some way they do believe that their texts do indeed refer to reality. These models of epistemology are metaphoric and thus indirectly describe reality and therefore metaphor plays a vital role in all epistemic models both religious and scientific. These models function with a certain commitment - either faith commitment or intellectual commitment - to a specific scientific or religious community.

These metaphors are not literal isomorphic pictures of reality, but they are also more than just useful fictions. "As such they are to be taken seriously but not literally, for although they refer in an ontological or cognitive sense, they are always partial and inadequate" (Van Huyssteen 1997:135). These metaphors of the epistemic models are embedded within history and cultural- 


\section{Postfoundationalism, deconstruction}

linguistic conventions. In other words they are part of the language community in which they arise, or are used. Does this mean we are back to our starting point and that we have moved in a circle? That everything is relative to the language community in which metaphors arise and are used? The temples we have constructed in our different communities still cannot really communicate with each other.

\subsection{Root metaphors}

Professor Van Huyssteen moves beyond this vicious circle with the concept of root metaphors, which brings us to the second tool for the construction of postfoundationalist temples. There are different models of interpretation and each of these models in their own way probe the "inner limits" of the texts ${ }^{2}$, or to use Paul Ricoeur's metaphor, to probe the itineraries of meaning which are contained in the text itself. If texts are limited then there cannot be an infinite number of fictions that can be interpreted or deduced from texts. "As such reading and interpretation is in a sense rule-governed and is in fact guided by a productive imagination at work in the text itself" (Van Huyssteen 1997:150).

Reading should be seen as the meeting place between the itineraries of meaning of the text and the imaginative power of the reader in redescribing reality, which is understood as metaphorization. Metaphorization is a process that is inherent in the text itself by virtue of its literary form. "The so-called itineraries of meaning, or (as I would phrase it) root metaphors, contained in the text are metaphorized through an act of creative, imaginative interpretation in the direction of a basic overall theme that governs the whole process of interpretation beyond the specific text" (Van Huyssteen 1997:150). This means that the texts themselves limit and guide the construction of temples. Within texts there is a process of metaphorization which restricts the interpretation of the itineraries of meaning. Certain texts have been interpreted over and over again in history and each time a reference is discovered or rediscovered and in that discovery or re-discovery of reference, a certain continuity or repetition can be identified. Thus this process provides a continuity of reference throughout history.

In postfoundationalism making use of critical realism and root metaphors we have discovered checks which limit the absolute relativism of nonfoundationalism and thus help construct temples that do not fall victim to the violence of the apathy of relativism.

\footnotetext{
${ }^{2}$ Texts understood in this context in the widest possible sense of texts (phenomena), as all that which can be interpreted.
} 


\subsection{Experiential adequacy, epistemological adequacy and approximate truth}

These different temples are now constructed with these root metaphors which are not just fictional creations, but have proven themselves to actually refer to something, not with absolute certainty, but not completely fictional either. Now these two temples (scientific and religious) can begin to communicate. Although what they refer to might be totally different, the reasoning strategies of construction do coincide and therefore they can take each other seriously. They can speak to each other because they know that the root metaphors being used are experientially as well as epistemologically adequate, and therefore these differing temples can speak of approximate truths.

Approximate truth means that there are adequate epistemic and experiential reasons to believe that this construction (this temple) does indeed suggest a certain truth. There are reasons to believe that the differing theories suggest truth (Van Huyssteen 1997:165-166).

It is on this basis of approximate truths that different researching communities working within the critical realist paradigm can enter into constructive dialogue with each other.

\subsection{Multi-disciplinary dialogue}

The different temples with their approximate truths can respect each other and thus enter into dialogue with each other, sharing their experientially adequate and epistemological adequate root metaphors and thereby constructing a fuller picture and maybe a truer picture of reality which can be described as optimal coherence (Van Huyssteen 2005).

There are certain localised constructions of reality which are localised perspectives of reality. If one would bring these different perspectives which are aware of their constructedness, but which are also approximate truths, into dialogue with each other, a fuller picture of truth is bound to be found. The local needs to be challenged and augmented by the global. All knowledge, which includes science, sociology, psychology and theology, is constructed, so that none of these epistemic disciplines has privileged access to reality. Therefore, the hope that inspires postfoundationalism is that if these different epistemic disciplines are in dialogue with each other, a fuller picture of reality might be constructed from the differing perspectives and therefore the different disciplines need each other - thus making multi-disciplinary work absolutely crucial. A new larger temple is constructed that brings together the building material, the insights and root metaphors of all the different disciplines, and thus provides hope that our research is actually part of a process to seek knowledge and better understanding of our experiences and 
"reality". In a sense we can say a transversal ${ }^{3}$ (Van Huyssteen 2005) temple has been created that incorporates all the different smaller local temples into one research community.

\section{THE POSTFOUNDATIONALIST MULTI-DISCIPLINARY TEMPLE}

We need to have a look at what kind of temple we have constructed. I would like to return to the prophetic vision of Isaiah. If one takes the historical and social setting of the book of Isaiah into consideration one is told by the Old Testament scholars that the first 39 chapters were written in a setting where the temple in Jerusalem and the people of Judah were flourishing. It was a prosperous time for both Judah and the temple faith in Jerusalem. Why then does the prophet begin his ministry by ignoring the existence of this temple in Jerusalem and exclusively speak of the temple that is to come? By ignoring the existence of the temple in Jerusalem he is deconstructing this temple not with violence but with the promise of the temple that is always still to come. This temple which is to come is one that will be above the mountains and the hills, in other words above reality, separate from reality, beyond reality.

With this promise of the temple that is always still to come, I would like to introduce some thoughts on deconstruction, understood within the context of my interpretations of the thoughts of Jacques Derrida.

\section{DECONSTRUCTION AND THE TEMPLE}

The temples must be built and must always again be built as the gathering of information and approximate truths is vitally important. But deconstruction is as important and these two need to go hand in hand in a certain dialectic relationship and it is in this dialectic that I find the hope that inspires research.

\subsection{Taking the temple absolutely seriously: Deconstruction, root metaphors, justice and hospitality}

Deconstruction cannot be defined, but it is often misunderstood as that which destroys traditions, institutions and "temples". It does question construction but not from outside with a destructive motive, but from within tradition motivated by the desire for the tradition to remain a living and hopeful

\footnotetext{
${ }^{3}$ The concept "transversal rationality" goes back to the German philosopher Wolfgang Welsch. "Transversale Vernunft ist beschränkter und offener zugleich. Sie geht von einer Rationalitätskonfiguration zu einer anderen über, artikuliert Unterscheidungen, knüpft Verbindungen und betreibt Auseinandersetzungen und Veränderungen. Ihr ganzes Prozedieren ist horizontal und übergängig, bleibt in diese transversale Typik gebunden. Es wird sich noch zeigen, daß diese Vernunft auch nicht nachträglich zu Totalsynthesen gelangt" (Welsch 1991:296).
} 
tradition. Derrida himself speaks of deconstruction in the following way: "not the mixture but the tension between memory, fidelity, the preservation of something that has been given to us, and, at the same time, heterogeneity, something absolutely new, and a break" (Derrida 1997:6).

Deconstruction means taking the tradition seriously, taking the texts seriously and taking the temple seriously, but it is not a way of commanding, repeating, or conserving this heritage. "It is an analysis which tries to find out how their thinking works (the thinking of the specific tradition/text) or does not work, to find the tensions, the contradictions, the heterogeneity within their own corpus" (Derrida 1997:9). Therefore one can argue that deconstruction works within traditions and constructions, taking the tradition, the constructions and the temple absolutely seriously, but questioning these constructions from within the tradition.

Yet deconstruction is not an analysis or a critique. "It is not an analysis in particular because the dismantling of a structure is not a regression toward a simple element, toward an indissoluble origin. These values, like that of analysis, are themselves philosophemes subject to deconstruction. No more is it a critique, in a general sense or in a Kantian sense. The instance of krinein or of krisis (decision, choice, judgment, discernment) is itself, as is all the apparatus of transcendental critique, one of the essential "themes" or "objects" of deconstruction" (Derrida 1988:3). For the same reasons deconstruction cannot be understood as a method.

Deconstruction seeks the heterogeneity within paradigms, traditions and temples. If we take the temple we have just created, we see that one of the building blocks was the idea of root metaphors. Any tradition or any corpus of texts, be it philosophical texts, theological texts or scientific texts, has these root metaphors. The metaphorization within these texts identifies certain themes. These themes crystallize out so that one could speak of, for example, the philosophy of Plato, or the ontology of Plato, or even of Platonism, or the theology of Karl Barth or the Einstein perspective. This would not be wrong: "there would undoubtedly be no error of principle in so speaking, merely an inevitable abstraction. Platonism would mean, in these conditions, the thesis or the theme which one has extracted by artifice, misprision, and abstraction from the text, torn out of the written fiction of "Plato". Once this abstraction has been supercharged and deployed, it will be extended over all the folds of the text, of its ruses, overdeterminations, and reserves, which the abstraction will come to cover up and dissimilate" (Derrida 1995:119). This abstraction as Derrida calls it is then called the "philosophy of Plato" or Platonism and this is neither arbitrary nor illegitimate, "since a certain 


\section{Postfoundationalism, deconstruction}

force of thetic ${ }^{4}$ abstraction at work in the heterogeneous text of Plato can recommend one to do so" (Derrida 1995:120). Derrida speaks of a certain thetic abstraction at work in a text and this can be compared to metaphorization and the development of root metaphors. This is not wrong. Although there is certain violence in this movement and domination of the text, this violence is legitimate, but it must never be understood as absolute. Deconstruction can be said to expose this violence of domination and is interested in the hidden or neutralised aspects of the text. A text is an ensemble without limit, although earlier I said that according to Van Huyssteen and Ricoeur texts are limited by the itineraries of meaning.

"In constructing itself, in being posed in its dominant form at a given moment, the text is neutralized in it, numbed, self-destructed, or dissimulated: unequally, partially, provisionally. The forces that are thus inhibited continue to maintain a certain disorder, some potential incoherence, and some heterogeneity in the organization of the theses" (Derrida 1995:120-121). In the texts therefore there is a certain auto-destruction. Deconstruction is thus not some method or tool that is used from outside the text, but something from inside the text/tradition (Derrida 1997:9). Therefore deconstruction can be situated within texts or within traditions or within paradigms. It is not a method with which to approach texts, traditions or paradigms because that very method will also in itself have a heterogeneity which will cause it to autodeconstruct. "Deconstruction takes place. It is an event that does not await the deliberation, consciousness, or organization of a subject, or even of modernity. It deconstructs it-self. It can be deconstructed. The "it" is not here an impersonal thing that is opposed to some egological subjectivity. It is in deconstruction ... to lose its construction" (Derrida 1988:4).

Deconstruction seeks the meanings and metaphors that have been displaced by the legitimate violence of the root metaphors. In all research and all epistemic models there are power motives, which play a role in the determination of root metaphors, both in the construction of texts as well as in the reading of texts. In texts there is a certain tendency towards propaganda and the creation or justification of ideologies.

Deconstruction does not say that there is no reference. "It is not that texts and language have no "referents" or "objectivity" but that the referent and objectivity are not what they pass themselves off to be, a pure transcendental signified" (Caputo 1997:80). Deconstruction challenges this ideal of a pure signified, as it is not pure, but embedded within various motives. Therefore deconstruction has

\footnotetext{
${ }^{4}$ Self identical.
} 
insisted not on multiplicity for itself but on heterogeneity, the difference, the disassociation, which is absolutely necessary for the relation to the other. What disrupts the totality is the condition for the relation to the other. The privilege granted to unity, to totality, to organic ensembles, to community as a homogenized whole - this is a danger for responsibility, for decision, for ethics and for politics.

(Derrida 1997:13)

These two should not be contrasted with each other as either or. Both unity and multiplicity are synonyms of death if taken alone and as absolute. It is not either foundationalism or non-foundationalism. What deconstruction is interested in is what happens at the limit of every attempt to totalize or to gather: "- the limit of this unifying, uniting movement, the limit that it had to encounter, because the relationship of the unity to itself implies some difference" (Derrida 1997:13). Deconstruction is interested in the temple once it is completed thereby not denying the construction of temples, but encouraging the construction of temples because we need them. But once it is completed it needs to be examined critically from within. There is always difference, never complete totality, and it is exactly this difference that opens the door to the other.

There are two movements, namely the movement of gathering and that of dissociating. Once you grant privilege to the one over the other you leave no room for the other, the foreign and the stranger or the unique outcome. "What is really going on in things, what is really happening, is always to come" (Caputo 1997:31). It is always the temple to come, the promise of the temple that questions the temple that is. What is really happening, what is going on is always eschatologically expected and therefore also always deferred into the expected future. If deconstruction deals with anything it deals with the impossible, and pursues the impossible. Traditions, paradigms, conventions, etcetera is all that which keeps the impossible out, which tries to gather around what the tradition or paradigm says to be essential, thereby closing off the tradition or paradigm from the future and the possibility of the impossible.

Deconstruction is the waiting, the expecting of justice for the other, of hospitality for the other and of democracy that includes the other. Within tradition there are numerous voices which have been unjustly treated, silenced and marginalised and these voices find a voice in deconstruction and a platform to speak, inspired by the justice to come. Deconstruction opens the door of hospitality to the stranger, the other, the tout autre of tradition and beyond tradition the wholly other who challenges the foundationalism of tradition. This is the democracy always still to come, the democracy where all 


\section{Postfoundationalism, deconstruction}

these different voices have a voice, the "hope in something radically pluralistic, plurivocal, multi-cultural, heteromorphic, heterological, and heteronomic," (Caputo 1997:174).

Deconstruction sees the temple that has been constructed with the root metaphors, and questions this construction by creating space for the other metaphors in the text. Deconstruction is the call for justice and hospitality that opens the doors for the temple to come, a temple for all nations who will come to seek its justice.

\subsection{Taking the temple absolutely seriously: Deconstruction, critical realism, the infinite play of traces/signifiers and the democracy to come}

What kind of temple have we created? What kind of realism is critical realism? I am not quite sure how to interpret critical realism and therefore I have thought of various possibilities, all taken from continental philosophy and not from within the paradigm of philosophy of science. This means that I will be mixing metaphors by bringing in the phenomenology of continental philosophy.

Husserl in his Logical Investigations distinguishes between "intention" (meaning, signification), and "fulfilment" (givenness), "according to which the ego "intends" or "means" an object which can only in varying degrees be "fulfilled" or "given" to intuition, whose total givenness remains always a regulative ideal for further experience" (Caputo \& Scanlon 1999:6). I believe that this idea coincides with critical realism, in other words that there is a reference within texts which refers to "reality", but total givenness remains always a regulative ideal for further experience. All approximate truths are inadequate. The meaning and the significance always remains inadequate and never complete, but the experiential and epistemological adequacy regulates the "progress" towards this impossible ideal of total givenness.

I believe this to be important because this determines the status and authority of the temple that has been created. There are different possibilities of interpreting critical realism. I will briefly look at three possibilities: Heidegger's deconstruction in the ontic-ontological difference, but which he later seeks to bridge either in the search for the origin (genesis) arché, or in an teleological expectation that one day it will be bridged; Jean-Luc Marion's excess/saturated interpretation of what is given which is a certain hyperessentialism; Derrida's understanding of khōra and the gift that is never given, but always hoped for.

Between texts and reality there is an unbridgeable gap. Derrida believes that Husserl discovered and then repressed the emancipation of 
language in that all we have is the structural capacity of the signifier without and in the absence of fulfilling intuition. The signifier has the structural capacity to convey meaning which is intended, but it is never fully given.

Heidegger reinterpreted truth (aletheia) not to mean correspondence, but truth to be the play between concealment and unconcealment. The essence, Being, is understood as presencing (unconcealment) but at the same time it is also concealment. Approximate truth can be situated between this play of concealment and unconcealment as in critical realism it is believed that there is a reference, but also no reference, at least not perfect or absolute reference. What Heidegger sought and questioned was the idea of an essential reality out there (Being) and that in every presence (being) there are essential traces of this essential reality. These traces could be understood as approximate truths. The different perspectives and constructions of reality all contain in their root metaphors traces of the essential reality and thus to bring these different perspectives together would provide a fuller picture of essential reality.

In Deconstruction there are no essential traces, only the play of traces - the continuous infinite play of signifiers. Derrida argues that there is a danger of determining différance as the difference between presencing and present: the ontological difference (Derrida 1973:158). As Heidegger is caught in the nostalgia and hope of finding the final word and the lost origin, according to deconstruction that quest needs to be rejected.

The greatest effort of metaphysical thinking has been driven by the desire and need to rescue Being from beings - to reinstitute a difference by examining beings and recovering their essence. Such an approach fails, not because there is no difference but because it does not understand properly the sameness of a being with its Being, a sameness which is already presupposed for the being to be. Being is always the Being of being. "It is only through a rethinking of this sameness that the meaning of the ontological difference can emerge in its proper sense" (Brogan 1988:34). For Heidegger the genitive of becomes important, as Beings emerge from Being and into Being and thus are. "Being gives itself to beings" (Brogan 1988:34). This movement is a genesis (Herkunft) of the present from presencing (Heidegger 1975:50). "It is the essence of this genesis that remains unthought in the history of metaphysics. Along with this failure to think through the essence of genesis, both presencing and that which is present as well as the relation between the two get misconstrued" (Brogan 1988:34). They are understood to be separate "somethings" that are then somehow related. The one finds its meaning in the other; the one side is a sign that points towards the other side 
which it signifies. "Presencing for example gets understood as a more primordial way of being present" (Brogan 1988:34).

It is the very formulation of the ontological difference that causes this distortion. This in-between is forgotten and not thought of. This forgetting is what generates metaphysics (Brogan 1988:34). Yet the original origin is forgotten - genesis is forgotten.

\begin{abstract}
Yet this letting appear and granting of difference while withdrawing, which is the peculiar "movement" of genesis, is still thought of by Heidegger in terms of Being and presencing, in other words in terms of one side of a difference (Being-beings) that already presupposes the metaphysical forgetfulness of the question of difference. This movement of the emerging of beings and withdrawing of Being, first, is the initiating of metaphysics; second is the meaning of difference; and third, is to be thought as the essence of Being and presencing and thus as the way in which one of the terms of the metaphysical opposition is to be understood.
\end{abstract}

(Brogan 1988:35)

To return for a moment to Heidegger's understanding of difference as genesis, we can summarize by saying that difference both originates and sustains that which emerges from it while holding itself back and allowing that which emerges to be on its own. "The uniqueness of genesis as movement (relation) lies in this sustaining power that originates all differences and draws them with it while withdrawing from it. Difference is a movement that never presents itself and can never present itself because it is what first opens up the space in which the presencing of beings that are present occurs" (Brogan 1988:35). The relation of difference to that which emerges from it cannot be fathomed or even approached from thinking that thinks only about what is. Only if this "isness" itself becomes questionable as such can thinking free itself to think the difference. The relation of difference to that which it differentiates is a chasm. "Heidegger's thinking is preparation for making the leap - a leap that requires us to translate what remains unsaid and unwritten within the history of metaphysics" (Brogan 1988:35).

What the thinking of difference calls for is to think the contradiction. It is the other that constitutes sameness, the Being that constitutes beings and Beingness, the presencing that constitutes presence and absence, the nothing that constitutes "isness" and nothingness. "But the nature of this constituting act and thus of this relation is such that it denies itself to that which it affirms, it holds itself to itself and thus crosses out its own constituting act, releasing this relation from bondage" (Brogan 1988:36). "It is genesis - 
the originary difference that is traced in this act that contradicts the origin even as it signifies it. It is the trace that differentiates while deferring its own difference. It is différance as Derrida portrays it" (Brogan 1988:36).

What Derrida objects to in Heidegger's understanding of ontological difference is that he names it as Being, as presencing, as unconcealment, and as that which Heidegger has shown are the traces that emerge from it. "There is an excess to difference which cannot be captured in the metaphysical text. The hermeneutic reading of such texts releases this overabundance and frees the movement that opens up new possibilities - it is this kind of reading/writing that inscribes itself at the arche or telos of metaphysics. Derrida understands Heidegger to believe that "the effacing of this early trace (die frühe Spur) of difference is therefore 'the same' as its tracing within the text of metaphysics" (Derrida 1975:156). But for Derrida it is not the same.

\begin{abstract}
The tracing within the text of metaphysics is an effect, a signature of différance which is itself a self-erasing trace. Différance is a trace that no longer belongs to the horizon of Being. Différance is not the genesis - the of and between that govern the emergence of beings. For Derrida, there is no genesis; merely the play of traces. This play doesn't assume the posture of rescuing that is common to metaphysics and phenomenology.
\end{abstract}

(Brogan 1988:37)

The question is: Does critical realism function on the basis of discovering these traces either in their origin or in an anticipated teleological future? Deconstruction avoids this telos as it interprets the traces to be the traces of traces and not the trace of the original (genesis) Spur. Another possibility of thinking about critical realism is found in the thoughts of Jean-Luc Marion who takes up these ideas of Heidegger. For him "it is a matter of releasing an excess of givens beyond the limits of any concept to conceive of or of any word to name it, a givenness that saturates any subjective condition or precondition that would contain its overflow or pre-delineate its possibility" (Caputo \& Scanlon 1999:8). There is an excess which cannot be contained in texts or in signifiers, but there are traces of this excess within the various texts. Then clearly the more texts you bring together the fuller the picture of reality will become. Derrida questions this hyperessentialism and contrasts it with his concept of Khōra (Caputo 1997:93).

As a third possibility Derrida understands this movement of hyperessentialism as having run up against an excess of transcendence, "a being of such supereminant sur-reality that, while giving birth to being, movement, and knowledge, it is itself beyond them all. Still, as the offspring of 


\section{Postfoundationalism, deconstruction}

its father and cause, the sensible world is "like" the ... (Caputo 1997:93) father. This means that that which becomes present in texts is the same as that which gives birth to it - presencing. This Being cannot be defined or described as known or intelligible, as visible or invisible. It is beyond all that, it is more than all that, but it is the cause, the medium and the intelligibility, of all that is.

Khōra constitutes another way of interpreting Being, another interpretation of the third thing that is beyond concealment and unconcealment, between visible and invisible, between intelligible and unintelligible. It is the opposite to what Marion has discovered, not hyper, but the opposite. It is not. It is not hyperexistence, but the opposite. It is not hyperessentialist but the opposite. It is not the excess which leaves traces in texts, but it is that in which giving takes place, leaving no traces, bringing us to the famous sentence: "all we have is the text". Therefore deconstruction does not seek this trace, either in the origin or in the anticipated future, but rather seeks the Messiah, the temple to come, the one that is to come and always is to come, deferred eschatology that calls for greater justice, for radical hospitality and true democracy. Justice interpreted from the Greek dike - that which makes space for the other, hospitality - that which welcomes the other and gives the home to the other, and democracy - that which gives space to the other voices (Derrida 2000).

Postfoundationalism searches for truth in the multi-disciplinary dialogue between the root metaphors of the different disciplines, whereas deconstruction searches for the other. It is not motivated by truth, but by justice, hospitality and democracy as it searches in the cracks, tensions and heterogeneity of these root metaphors, thereby keeping tradition alive, keeping foundations open to that which is to come: the incoming of the other, the stranger, the one not yet heard.

\section{CONCLUSION}

I would like to end where I began with the text from Isaiah, as I believe this text calls us from the depths of the chasm, the crack in the mountain in which Elijah sat. This is the indefinable whispering of a promise that gives hope to continue researching, building the postfoundationalist temples and then remembering that the task is not finished, not because we have not discovered the final truth, but because we do not have justice. There are still metaphors unheard, hospitality not given to whispering voices, and uninvited guests and true democracy always still to come - if such things exist. 


\section{Works consulted}

Brogan, W A 1988. The original difference, in Wood, D \& Bernasconi, R (eds), Derrida and Différance. Evanston, IL: Northwestern University Press.

Caputo, J D (edited with a commentary) 1997. Deconstruction in a nutshell: $A$ conversation with Jacques Derrida. New York: Fordham University Press.

Caputo, J D \& Scanlon, M J 1999. Introduction, in Caputo, J D \& Scanlon, M J (eds), God, the gift, and postmodernism. Bloomington, IN: Indiana University Press.

Derrida, J 1973. Speech and phenomena, tr by D Allison. Evanston, IL: Northwestern University Press.

Derrida, J 1988. Letter to a Japanese friend in Derrida and Difference, in Wood, D \& Bernasconi, R (eds), Evanston IL: Northwestern University Press.

Derrida, J 1995. Khōra, in Dutoit, T, On the name: Jacques Derrida. Stanford: Stanford University Press.

Derrida, J 1997. The Villanova roundtable: A conversation with Jacques Derrida, in Caputo, J D (edited with a commentary) Deconstruction in a nutshell: $A$ conversation with Jacques Derrida. New York: Fordham University Press.

Derrida, J 2000. Step of hospitality/No hospitality (Pas d'hospitalité), in Of hospitality: Anne Dufourmantelle invites Jacques Derrida to respond: Cultural memory in the present, tr by Bowlby. Stanford: Stanford University Press.

Dutoit, T (ed) 1995. On the name: Jacques Derrida. Stanford: Stanford University Press.

Heidegger, M 1975. The anaximander fragment, in Early Greek thinking, tr by D F Krell, \& R F Capuzzi. New York: Harper \& Row.

Van Huyssteen, W 1997. Essays in Postfoundationalist Theology. Grand Rapids, MI: Eerdmans.

Van Huyssteen, W 2005. Discussions with W van Huyssteen at a Practical TheologySeminar: In conversation with Prof Wentzel van Huyssteen about Postfoundationalism and Practical Theology. Held at the Suid-Oos Pretoria Dutch Reformed Church, organised by Professor Julian Müller of the University of Pretoria on the $1^{\text {st }}$ of August 2005.

Welsch, W 1991. Unsere postmoderne Moderne. Dritte Auflage Weinheim: VCH, Acta Humaniora.

Wood, D \& Bernasconi, R (eds) 1988. Derrida and Différance. Evanston, IL: Northwestern University Press. 